\title{
A new species of the thorid shrimp genus Eualus Thallwitz, 1892 (Crustacea: Decapoda: Caridea) from the Bering Sea, with notes on related species
}

\author{
Новый вид торидной креветки из рода Eualus Thallwitz, 1892 \\ (Crustacea: Decapoda: Thoridae) из Берингова моря \\ с замечаниями о близких видах
}

\author{
Tomoyuki Komai ${ }^{1}$, Sammy De Grave ${ }^{2}$ \\ Томоюки Комаи ${ }^{1}$, Сэмми Ае Граве
}

\author{
${ }^{1}$ Natural History Museum and Institute, Chiba, 955-2 Aoba-cho, Chuo-ku, Chiba, 260-8682 Japan. E-mail: komai@chiba-muse.or.jp \\ (corresponding author) \\ ${ }^{2}$ Oxford University Museum of Natural History, Parks Road, Oxford, OX1 3PW, U.K. E-mail: sammy.degrave@oum.ox.ac.uk
}

KEY WORDS: Eualus zarenkovi, new species, Eualus belcheri, Eualus ratmanovi, Bering Sea, Arctic, sexual dimorphism.

КЛЮЧЕВЫЕ СЛОВА: Eualus zarenkovi, новый вид, Eualus belcheri, Eualus ratmanovi, Берингово море, Арктика, половой диморфизм.

ABSTRACT. Examination of material from the Bering Sea led us to reevaluate the specific identity of a thorid shrimp taxon Eualus ratmanovi Makarov, 1941 (Decapoda: Caridea), originally described from the Bering Sea. From morphological comparison of available material, we came to a conclusion that E. ratmanovi is a junior subjective synonym of $E$. belcheri (Bell, 1855), and that E. belcheri is specifically distinct from E. gaimardii (H. Milne Edwards, 1837), not a subspecies of the latter. The material from the Bering Sea is here attributed to a new species, E. zarenkovi sp.n. The three species treated in this study are primarily differentiated by the development and shape of the middorsal protuberance on the third pleomere. Other distinguishing characters include the rostral shape and armature, the length and armature of the telson, the length of the antennular stylocerite, the length of the third maxilliped, and the proportion of the dactylus of the third pereopod. Many of these diagnostic characters are influenced by sexual dimorphism, requiring careful comparison according to the sex.

РЕЗЮМЕ. Исследование материала из Берингова моря побудило нас пересмотреть видовую принадлежность торидной креветки Eualus ratmanovi Makarov, 1941 (Decapoda: Caridea), описанной из Берингова моря. На основе морфологического сопоставления имевшегося материала мы пришли к выводу, что E. ratmanovi является младшим субъективным синонимом $E$. belcheri (Bell, 1855), и что $E$. belcheri не является подвидом E. gaimardii (H. Milne Edwards, 1837), а отличается от него на видовом уровне. Материал из Берингова моря отнесен к но- вому виду E. zarenkovi sp.n. Три вида, рассматриваемые в данном исследовании отличаются, прежде всего, степенью развития и формой дорсального выступа на третьем плеомере (сегменте абдомена). Другие отличительные признаки включают форму и вооружение рострума, длину и вооружение тельсона, длину стилоцерита антеннул и пропорции дактиля переопод третьей пары. Многие из этих диагностических признаков подвержены половому диморфизму, что требует их тщательного сравнения у особей разных полов.

\section{Introduction}

The thorid shrimp genus Eualus Thallwitz, 1892 is represented by about 40 species worldwide [De Grave, Fransen, 2011; updated by Komai, Fujiwara, 2012; Nye, 2013], of which about 25 species occur in the North Pacific [Rathbun, 1904; Brashnikov, 1907; Kobjakova, 1937, 1955; Makarov, 1941; Miyake, Hayashi, 1967; Butler, 1980; Carvacho, Olson, 1984; Wicksten, 1990; Hayashi, 1993; Komai, Hayashi, 2003; Komai, Fujiwara, 2012]. In older systematic works, this genus was placed in the family Hippolytidae, but De Grave et al. (2014) unraveled the systematics of this family, and recognized five families, including Thoridae, which is herein followed.

The taxonomic identity of some specific taxa remains rather obscure, e.g. E. bulychevae Kobjakova, 1955 and E. ratmanovi Makarov, 1941 [see e.g. Nöel 1978; Komai, Fujiwara 2012]. The status of E. gaimardii (H. Milne Edwards, 1837) and E. belcheri (Bell, $1855)$ has been controversial, and has been variously 


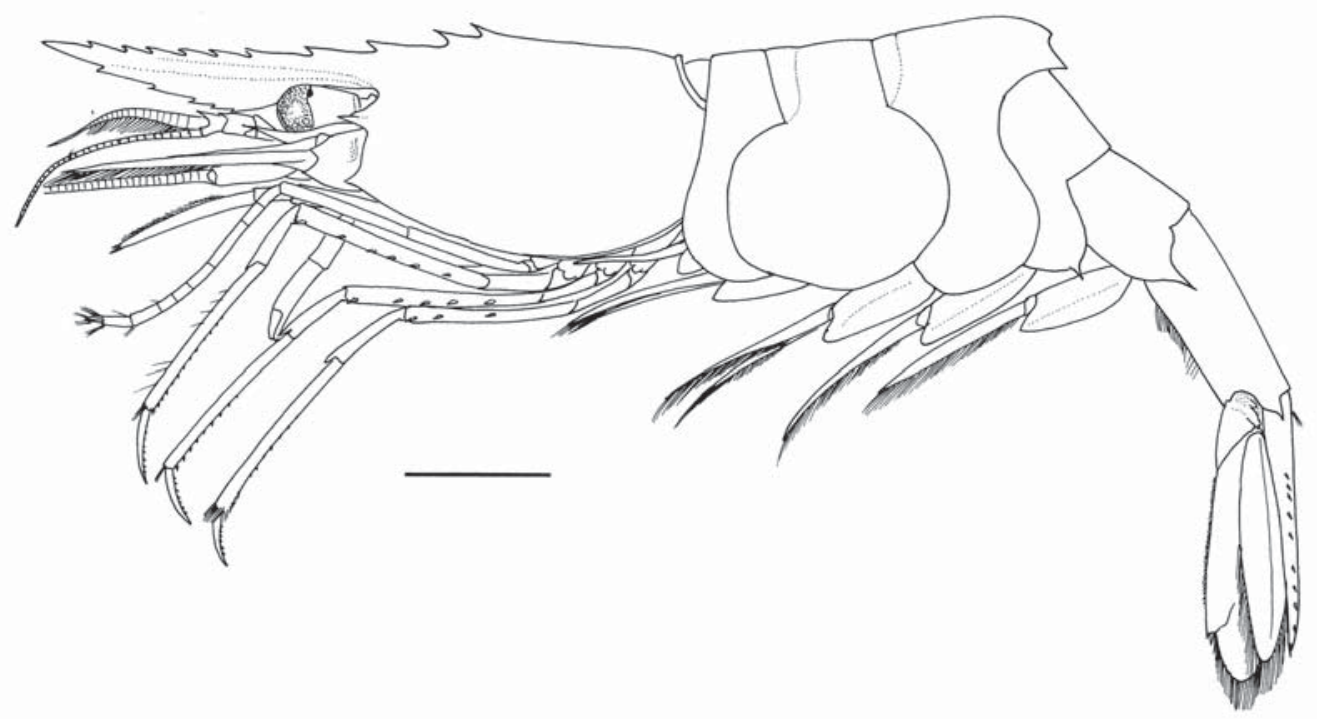

Fig. 1. Eualus zarenkovi sp.n., ovigerous female (cl $10.5 \mathrm{~mm}$ ), CBM-ZC 13080, entire animal in lateral view. Scale bar: $5 \mathrm{~mm}$.

Рис. 1. Eualus zarenkovi sp.n., яйценосная самка (cl 10,5 мм), СВM-ZC 13080, целый экземпляр, вид сбоку. Масштабная линейка: 5 мм.

treated as separate, full species or with E. belcheri considered a subspecies of E. gaimardii [e.g. Couture, Trudel 1976; Williams, 1984; Squires, 1990; d'Udekem d'Acoz, 1999; De Grave, Fransen, 2011].

This study was initiated to identify material collected from the Bering Sea, off St. Lawrence Island during the 1991 cruise to the North Pacific by the T/S "Oshoromaru" of the Faculty of Fisheries, Hokkaido University. In the process of attempting to identify the specimens with available literature, it became apparent that the true identity of Eualus ratmanovi, originally described from the Bering Sea, is difficult to establish. Examination of the original description of E. ratmanovi as well as photos of the type series supplied by V.Petryashov, however, has disclosed that E. ratmanovi should be considered to be identical with $E$. belcheri, and that E. gaimardii belcheri sensu Makarov [1941] might be identical with the present specimens from the Bering Sea. In this study, we propose to designate the specimen illustrated by Makarov [1941] as a lectotype of E. ratmanovi, thus effectively making Makarov's [1941] taxon a junior subjective synonym of E. belcheri. A new species, E. zarenkovi, is described and illustrated on the basis of the current Bering Sea specimens, as they can not be assigned to any previously described species. Differentiating characters among the new species, E. belcheri and E. gaimardii were identified through morphological comparison of available specimens, further warranting full specific status for E. gaimardii and E. belcheri.

\section{Material and Methods}

Specimens examined in this study are deposited in the Laboratory of Marine Biology and Biodiversity,
Faculty of Fisheries, Hokkaido University (HUMZ), Natural History Museum and Institute, Chiba (CBM), the Zoological Collection of the Oxford Museum of Natural History, Oxford (OUMNH.ZC) and the Zoological Institute of Russian Academy of Sciences, St Petersburg (ZIN RAN). Carapace length (cl) represents specimen size, measured from the posterior margin of the orbit to the midpoint of the posterodorsal margin of the carapace. Third to fifth pereopods are generally similar in the three species treated in this study; the third pereopod is used as a representative of the three appendages for comparison.

For comparison, the following material was examined.

Eualus belcheri. Holotype: male (cl $8.4 \mathrm{~mm}$ ), OUM 10021, Canadian Arctic Archipelago, between Beechey Island and Northumberland Sound, 1852-1854.

Other material: 1 female (cl $12.4 \mathrm{~mm}$ ), HUMZ-C 1290, RV "Shinkai-maru", Stn T-109, Davis Strait, Greenland, $69^{\circ} 34.8^{\prime} \mathrm{N}$, $58^{\circ} 48.7^{\prime} \mathrm{W}, 577-580 \mathrm{~m}, 25$ August 1991, otter trawl, coll. Hiromitsu Endo; 1 female (cl $17.0 \mathrm{~mm}$ ), 1 male (cl $15.1 \mathrm{~mm}$ ), HNMZ-C 1292, Stn T-121, Davis Strait, $69^{\circ} 27.8^{\prime} \mathrm{N}, 55^{\circ} 33.4^{\prime} \mathrm{W}, 254 \mathrm{~m}$, 27.08.1991, coll. H. Endo; 3 females (cl 16.2-18.9 mm), HUMZ-C 1379, Stn T-117, Davis Strait, $69^{\circ} 44.2^{\prime} \mathrm{N}, 57^{\circ} 00.5^{\prime} \mathrm{W}, 201 \mathrm{~m}$, 26.08.1991, otter trawl, coll. H. Endo; 2 males (cl 9.6, $14.1 \mathrm{~mm}$ ), 8 females (cl 9.9-17.0 mm), HUMZ-C 1390, Stn T-119, Davis Strait, $69^{\circ} 30.0^{\prime} \mathrm{N}, 56^{\circ} 25.7^{\prime} \mathrm{W}, 229 \mathrm{~m}$, otter trawl, 27.08.1991, coll. H. Endo; 1 male (cl $14.9 \mathrm{~mm}$ ), 4 females (cl 16.8-19.0 mm), HUMZC 1425 , Stn T-120, Davis Strait, $69^{\circ} 27.2^{\prime} \mathrm{N}, 55^{\circ} 51.7^{\prime} \mathrm{W}, 239-245$ m, 27.08.1991, otter trawl, coll. H. Endo.

Eualus gaimardii. 8 females (cl 6.9-10.7 mm), 2 ovigerous females (cl 9.2, 10.5 mm), HUMZ-C 1395, RV "Shinkai-maru", Stn T-139, Davis Strait, $67^{\circ} 39.6^{\prime} \mathrm{N}, 55^{\circ} 20.5^{\prime} \mathrm{W}, 57-59 \mathrm{~m}$, otter trawl, 30.08.1991, coll. H. Endo; 3 males (cl 6.3-7.7 mm), 5 females $(5.6-10.0 \mathrm{~mm}), 7$ ovigerous females $(\mathrm{cl} 8.3-11.7 \mathrm{~mm})$, OUMNH-ZC.2003-31-08, RV "Jan Mayen", Stn 129, Svalbard, Norway, $79^{\circ} 33.5^{\prime} \mathrm{N}, 11^{\circ} 07.8^{\prime} \mathrm{E}, 135 \mathrm{~m}$, trawl, 18.09 .2003 , coll. C. d'Udekem d'Acoz. 


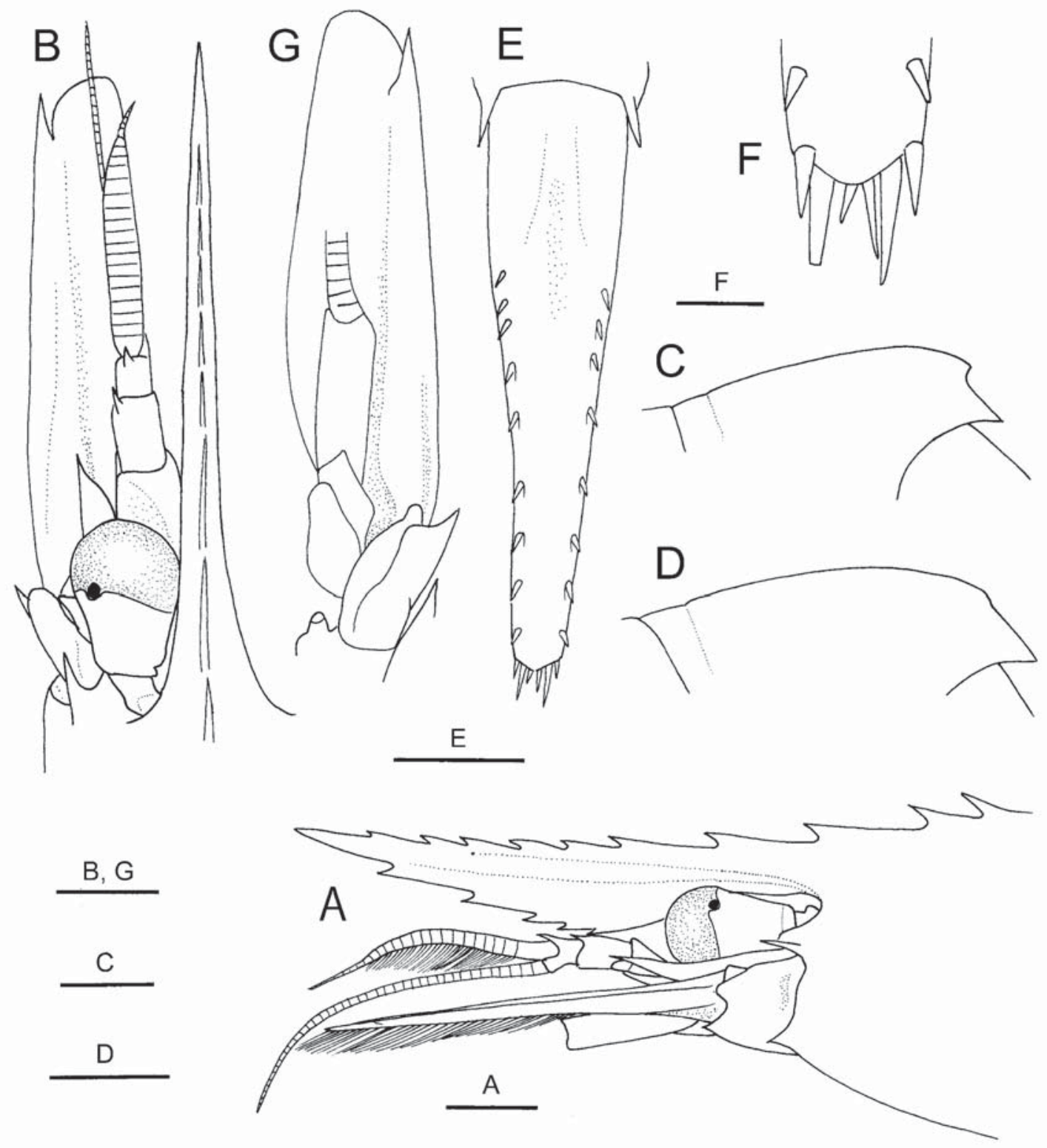

Fig. 2. Eualus zarenkovi sp.n., A-C, E-G, ovigerous female (cl $10.5 \mathrm{~mm}$ ), CBM-ZC 13080; D, female (cl 9.0 mm), CBM-ZC 12096. A - anterior part of carapace and cephalic appendages, lateral view; B - anterior part of carapace and cephalic appendages, left side, dorsal view (setae omitted); C, D - 3rd pleonal tergite, lateral view; E - telson, dorsal view; F - same, posterior part, dorsal view (setae omitted). Scale bars: $2 \mathrm{~mm}$ for A-E; $0.5 \mathrm{~mm}$ for F.

Pис. 2. Eualus zarenkovi sp.n., A-C, E-G, яйценосная самка (cl 10,5 мм), CBM-ZC 13080; D, самка (cl 9,0 мм), CBM-ZC 12096. A - передняя часть карапакса и грудных придатков, вид сбоку; В - передняя часть карапакса и грудных придатков, левая сторона, вид сверху (щетинки не показаны); C, D - 3-й плеональный тергит, вид сбоку; Е — тельсон, вид сверху; F — то же, задняя часть, вид сверху (щетинки не показаны). Масштабные линейки: 2 мм для A-E; 0,5 мм для F.

\section{Taxonomy}

Order DECAPODA Latreille, 1802

Family THORIDAE Kingsley, 1879

Genus Eualus Thallwitz, 1892

\section{Eualus zarenkovi sp.n.}

Figs. 1-4.

Spirontocaris gaimardii belcheri: Rathbun, 1904: 86 (in part), pl. III, fig. 3, 3a.
Eualus gaimardii belcheri: Makarov, 1941: 125, fig. 10a (not fig. 10b), 163; Vinogradov, 1950: 207 (key).

MATERIAL EXAMINED. Holotype: ovigerous female (cl 10.4 $\mathrm{mm}$ ), CBM-ZC 13080, T/S "Oshoro-maru", cruise 38, Stn OST$9101, \mathrm{~S}$ of St. Lawrence Island, Bering Sea, $62^{\circ} 38.4^{\prime} \mathrm{N}, 171^{\circ} 14.7^{\prime} \mathrm{W}$, $47 \mathrm{~m}$, otter trawl, 21.07.1991, coll. Mamoru Yabe.

Paratypes: 1 female (cl $9.1 \mathrm{~mm}$ ), 6 ovigerous females (cl 10.1-10.7 mm), HUMZ-C 1361, same data as holotype; 1 female (cl $11.7 \mathrm{~mm}$ ), 3 ovigerous females (cl 9.6-12.6 mm), HUMZ-C 1364 , Stn OST-9102, S of St. Laurence Island, $62^{\circ} 27.5^{\prime} \mathrm{N}$, $169^{\circ} 35.3^{\prime} \mathrm{W}, 30 \mathrm{~m}$, otter trawl, 22.07.1991, coll. M. Yabe; 2 males (cl 7.6, $7.8 \mathrm{~mm}$ ), 3 females $(\mathrm{cl} 7.2-9.0 \mathrm{~mm}$ ), CBM-ZC 

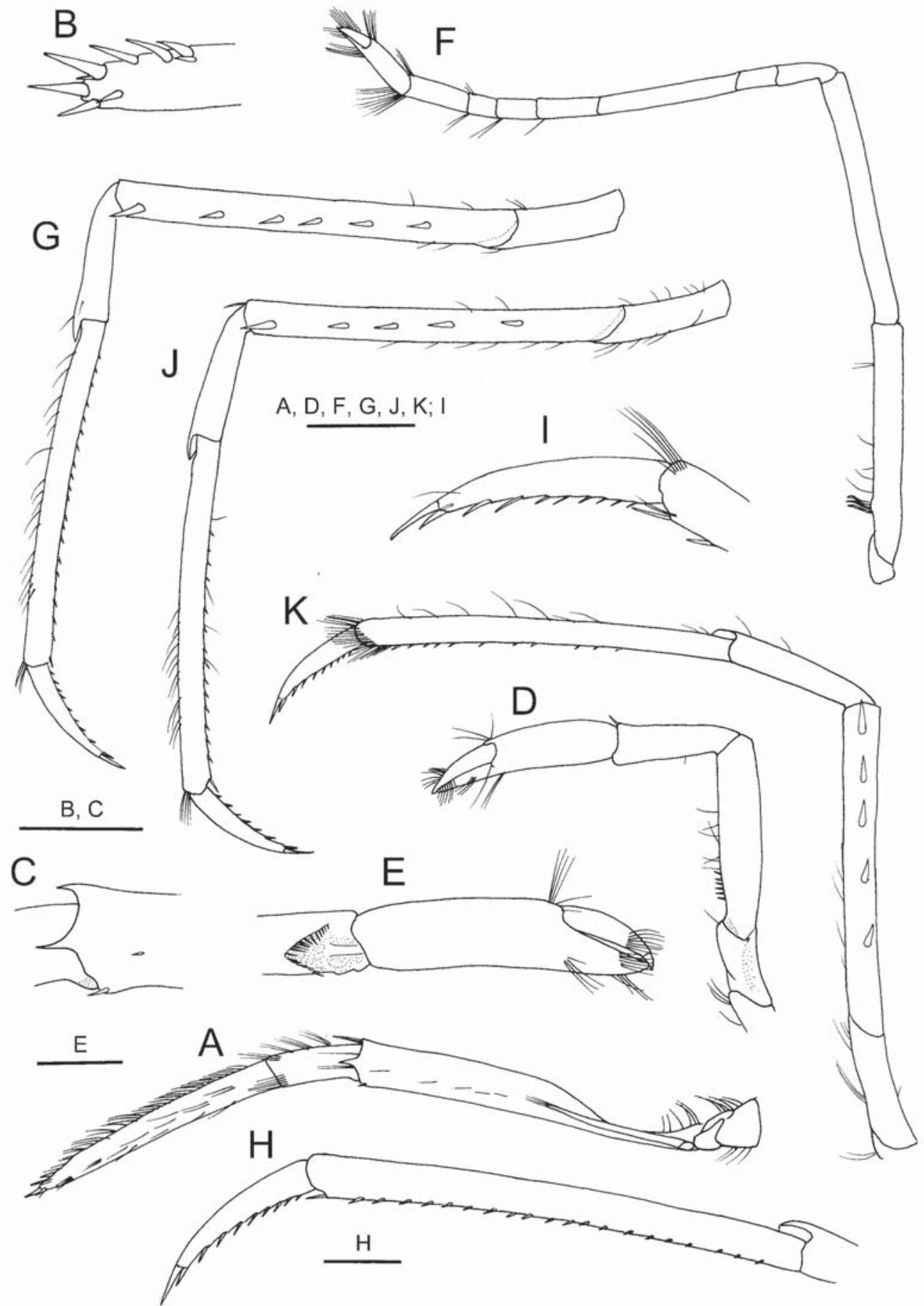

Fig. 3. Eualus zarenkovi sp.n., ovigerous female (cl $10.5 \mathrm{~mm}$ ), CBM-ZC 13080. Left thoracic appendages. A — third maxilliped, lateral view; B — same, distal part of ultimate segment, dorsal (extensor) view; C — same, distal part of antepenultimate segment, lateral view; D - 1st pereopod, lateral view; E — same, chela, ventral (flexor) view; F - 2nd pereopod, lateral view; G - 3rd pereopod, lateral view; H - same, dactylus and propodus, lateral view; I — same, dactylus, lateral view; J - 4th pereopod, lateral view; $\mathrm{K}$ - 5th pereopod, lateral view. Scale bars: $2 \mathrm{~mm}$ for A, D, F, G, J, K; $1 \mathrm{~mm}$ for B, C, E, H, I.

Рис. 3. Eualus zarenkovi sp.n., яйценосная самка (cl 10,5 мм), СBM-ZC 13080. Левые торакальные конечности. А — максиллипед 3-й пары, вид сбоку; В - то же, дистальная часть конечного членика, дорсальный (со стороны extensor) вид; С — то же, дистальная часть переднего предконцевого членика, вид сбоку; D - переопод 1-й пары, вид сбоку; Е - то же, клешня, вентральный (со стороны flexor) вид; F — переопод 2-й пары, вид сбоку; G - переопод 3-й пары, вид сбоку; Н — то же, дактиль и пропод, вид сбоку; I - то же, дактиль, вид сбоку; J - переопод 4-й пары, вид сбоку; К - переопод 5-й пары, вид сбоку. Масштабные линейки: 2 мм для A, D, F, G, J, K; 1 мм для В, C, E, Н, I. 


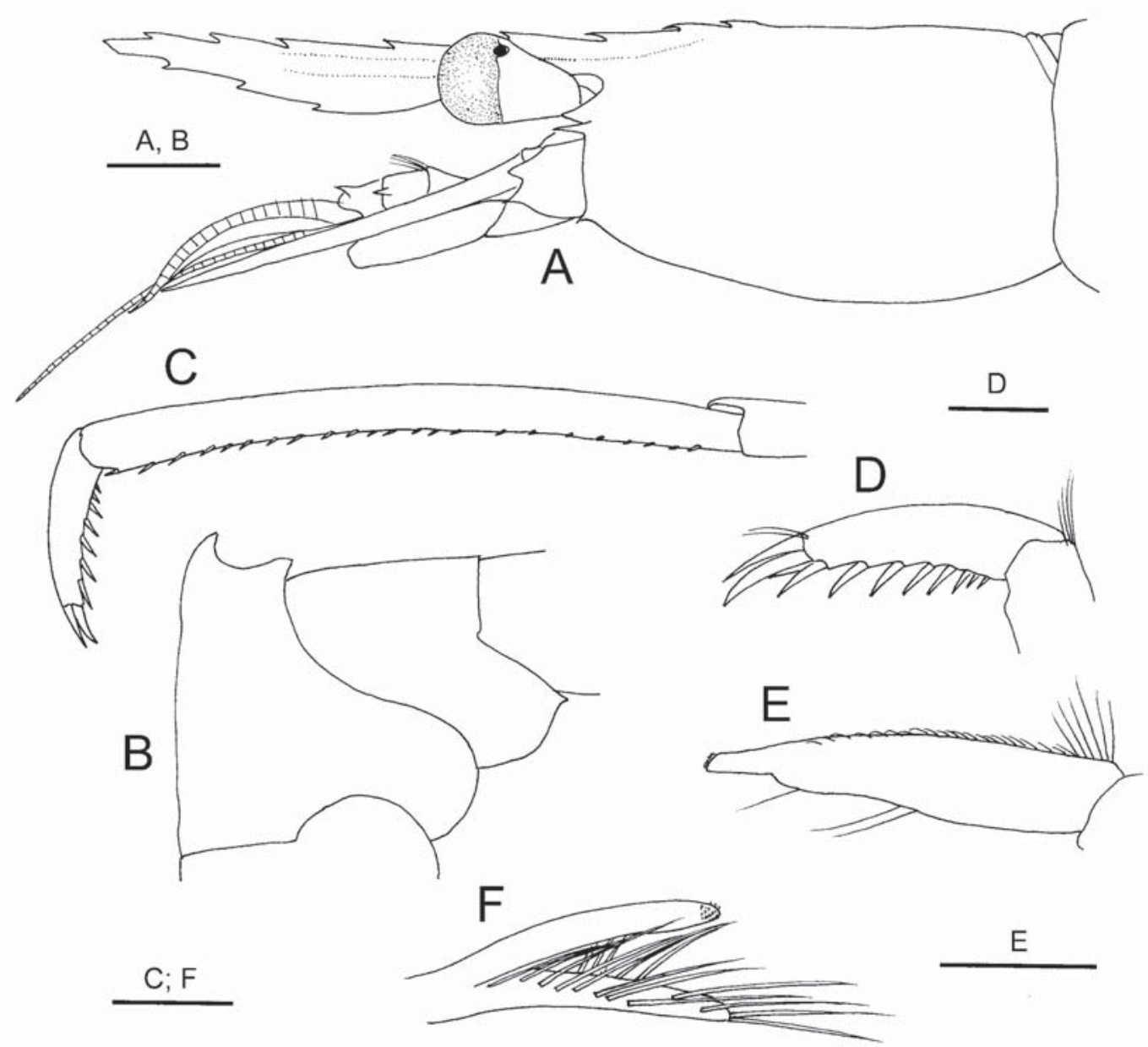

Fig. 4. Eualus zarenkovi sp.n. A, B - male (cl $7.6 \mathrm{~mm})$, CBM-ZC 12096; C-F — male (cl 7.8 mm), same lot. A - carapace and cephalic appendages, lateral view; B - 3rd and 4th pleonal somites, lateral view; C - dactylus and propodus of left third pereopod, lateral view; D - dactylus of left 3rd pereopod, lateral view; E - endopod of left 1st pleopod, dorsal view; F — appendices interna and masculina of left 2nd pleopod, mesial view. Scale bars: $2 \mathrm{~mm}$ for A, B; $1 \mathrm{~mm}$ for C, E; $0.5 \mathrm{~mm}$ for D, F.

Рис. 4. Eualus zarenkovi sp.n. А, В - самец (cl 7,6 мм), CBM-ZC 12096; C-F — самец (сl 7,8 мм), тот же лот. А — карапакс и цефалические придатки, вид сбоку; В - 3-й и 4-й плеональные сомиты, вид сбоку; С - дактиль и пропод левой переоподы 3-й пары, вид сбоку; D - дактиль, левой переоподы 3-й пары, вид сбоку; E - эндопод левой переоподы 1-й пары, вид сверху; F appendici interna et masculina левой переоподы 2-й пары, мезиальный вид. Масштабные линейки: 2 mm для A, B; 1 mm for C, E; 0,5 мм для D, F

12096, 2 females (cl 6.1, $8.2 \mathrm{~mm}$ ), OUMNH.ZC.2015-02-006, exact station unknown.

DESCRIPTION. Adult females. Body (Fig. 1) moderately slender. Rostrum (Figs 1, 2A) 1.1-1.5 length of carapace (mean $1.25, \mathrm{n}=9$ ), nearly straight to gently upturned, reaching or slightly overreaching anterior margin of antennal scale; dorsal margin armed with 710 moderately spaced teeth, including 5-7 on rostrum proper and 2 or 3 postrostral (posteriormost tooth located at about 0.3 of carapace length), distal 0.15 or less unarmed; ventral blade well developed with convex ventral margin, deepest slightly proximal to midlength, armed with 3-5 widely spaced teeth; obsolescent lateral carina discernible. Carapace (Fig. 1) with dorsal margin nearly straight, postrostral carina low, not reaching to midlength; antennal tooth moderately strong; inferior orbital angle triangular with subacute apex, clearly separated from antennal tooth; pterygostomial tooth moderately strong; anterolateral margin between antennal and pterygostomial teeth slightly sinuous.

Pleon (Fig. 1) somewhat gibbous; tergites of first, second, fourth to sixth somites rounded, that of third somite with small, slightly hook-like median protuberance with posteriorly directed, blunt apex on posterior part in adults (Fig. 2C); in small females $(\mathrm{cl}<9.0 \mathrm{~mm})$, median protuberance obsolescent (Fig. 2D); posterodorsal margin of third somite markedly produced posteriorly (but not spiniform), those of fourth an fifth somites unarmed. Fourth and fifth pleura each with strong posteroventral tooth (tooth on fifth much stronger than that on fourth). Sixth pleomere about 2.0 times as long as fifth, 2.3-2.5 times longer than high; posterolateral tooth terminating in slender, acute tooth; tiny posteroventral tooth present. Telson (Fig. 2E) 1.16- 


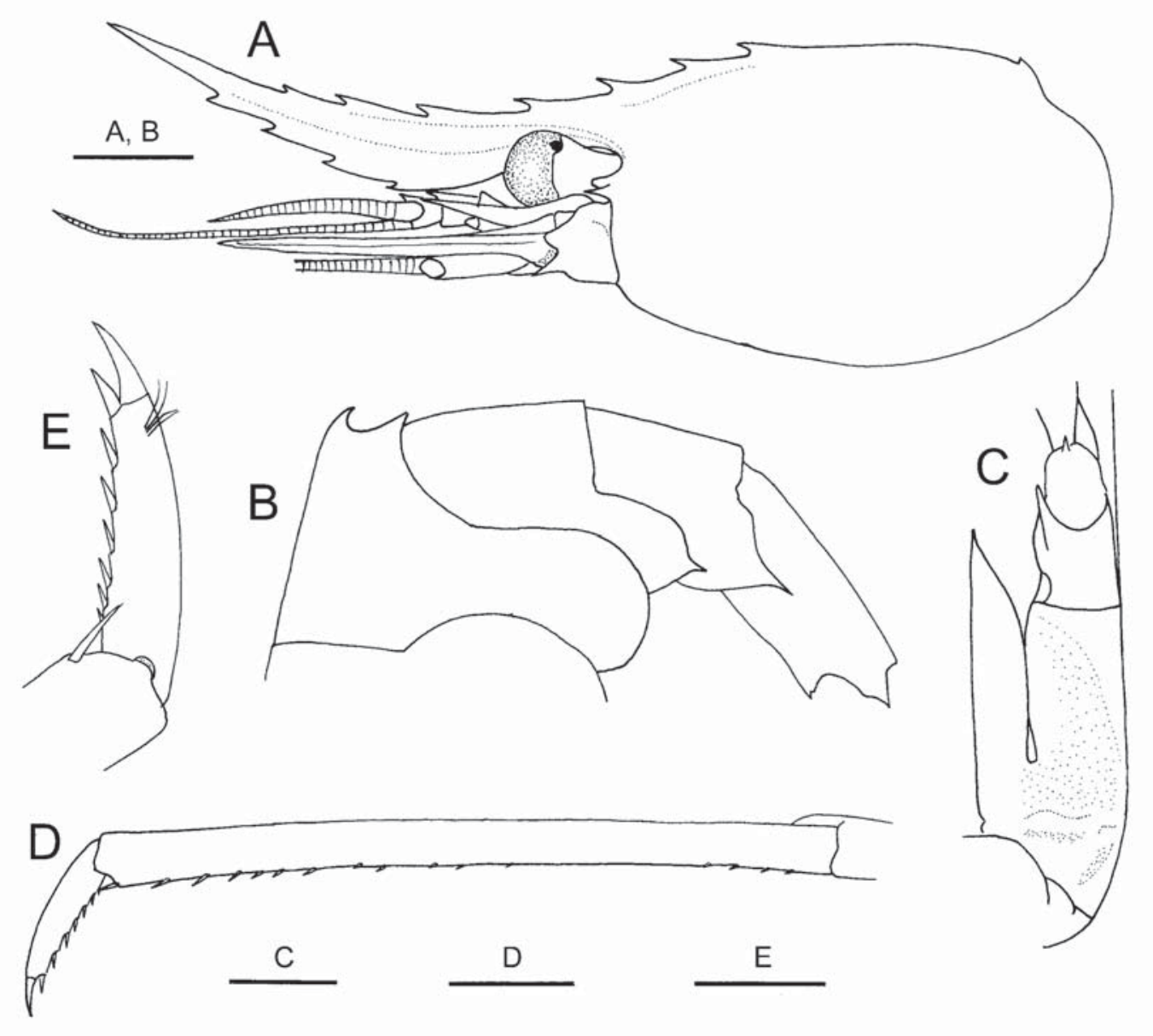

Fig. 5. Eualus belcheri (Bell, 1855), female (cl $16.5 \mathrm{~mm}$ ), HUMZ-C 1292. A — carapace and cephalic appendages, lateral view; B 3 rd to 6 th pleonal somites, lateral view; $\mathrm{C}$ - left antennular peduncle, dorsal view; D - dactylus and propodus of left 3rd pereopod, lateral view; E - dactylus of left 3rd pereopod, lateral view. Scale bars: $5 \mathrm{~mm}$ for A, B; $2 \mathrm{~mm}$ for C, D; $1 \mathrm{~mm}$ for E.

Рис. 5. Eualus belcheri (Bell, 1855), самка (cl 16,5 мм), HUMZ-C 1292. А — карапакс и цефалические придатки, вид сбоку; В 3-6-й плеональные сомиты, вид сбоку; С - левый стебелек антеннулы, вид сверху; D - дактиль и пропод левого переопода 3-й пары, вид сбоку; Е - дактиль левого переопода 3-й пары, вид сбоку. Масштабные линейки: 5 мм для А, В; 2 мм для C, D; 1 мм для Е.

$1.36(\mathrm{n}=8$; mean 1.27$)$ times as long as sixth pleomere, 4.3-4.4 times longer than anterior width; lateral margins parallel in anterior 0.3 , narrowing thereafter to gently convex posterior margin; dorsal surface with 69 dorsolateral spines on either side (excluding 1 pair at posterolateral corner); posterior margin (Fig. 2F) with 3 pairs of spines (second pair longest).

Eye (Fig. 2A, B) subpyriform; cornea bearing ocellar spot, corneal width less than 0.2 of carapace length.

Antennular peduncle (Fig. 2A, B) reaching nearly to midlength of antennal scale. Basal segment unarmed on dorsodistal margin; ventromesial ridge with small tooth subdistally; stylocerite overreaching distal margin of basal segment, but not reaching distal margin of second segment, terminating in acute tooth, without proximolateral process. Distal two segments combined distinctly shorter than basal segment, each with small tooth on distal margin. Outer flagellum with thickened aesthetasc-bearing portion about 0.4 length of carapace; inner flagellum about 1.5 length of outer flagellum.
Antenna (Fig. 2A, B) with basicerite bearing small ventrolateral distal tooth, dorsolateral distal angle rounded. Carpocerite slightly falling short of midlength of antennal scale. Antennal scale about 0.8 times as long as carapace, about 3.5 times longer than wide; lateral margin nearly straight; distolateral tooth falling short of rounded distal margin of blade.

Mouthparts not dissected. Third maxilliped (Figs 1, 3A) not reaching distal margin of antennal scale; ultimate segment about 2.7 times as long as penultimate segment (= carpus), gradually tapering distally, distal margin bearing some small spines arranged in row along margins (Fig.3B); antepenultimate segment subequal in length to distal two segments combined, dorsodistal margin with minute tooth, distolateral margin with prominent tooth (Fig. 3C). Coxa with straplike, terminally hooked epipod.

Strap-like, terminally hooked epipods on first and second pereopods and corresponding setobranchs on coxae of second and third pereopods respectively. 


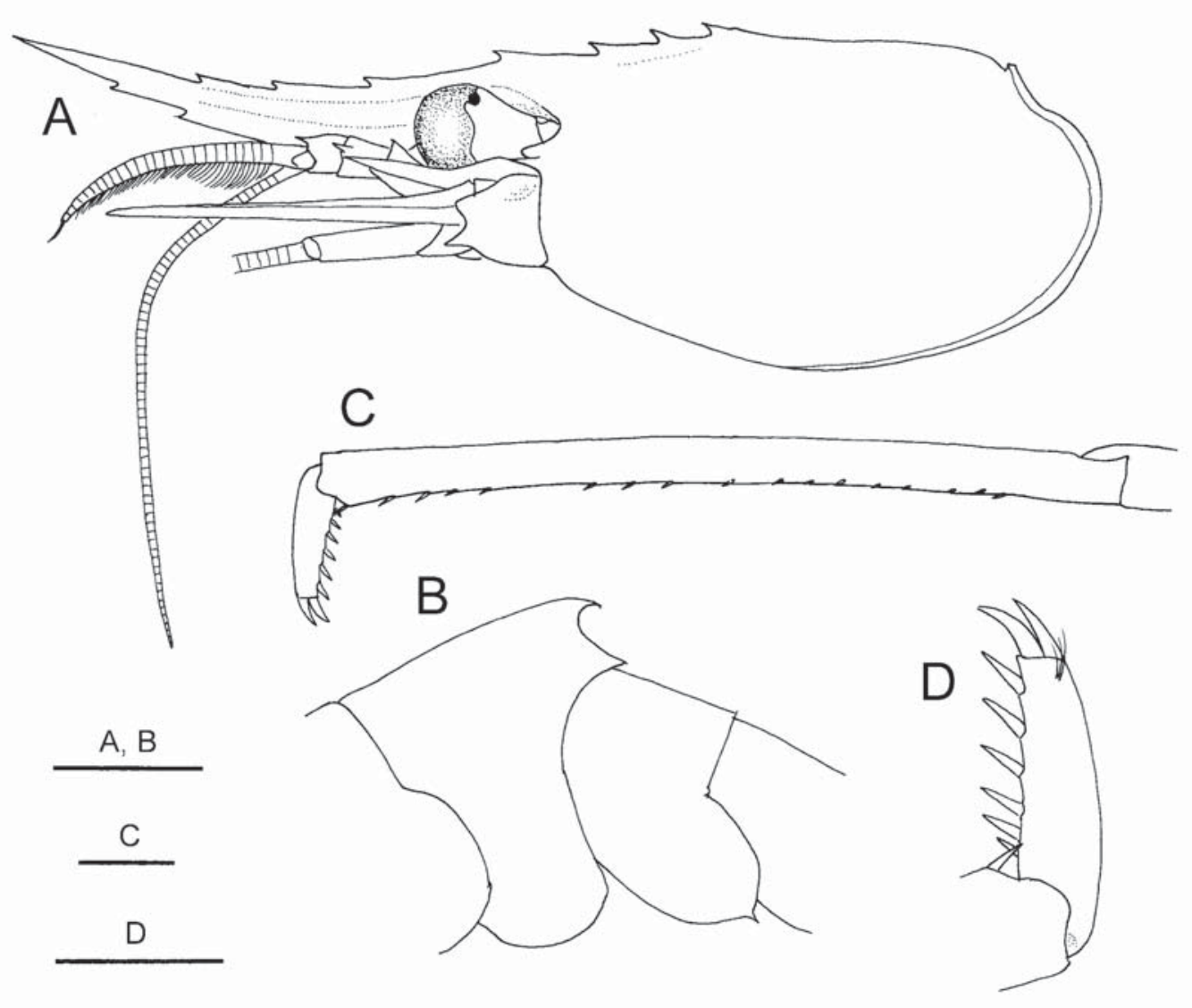

Fig. 6. Eualus belcheri (Bell, 1855), male (cl $15.2 \mathrm{~mm}$ ), HUMZ-C 1425. A — carapace and cephalic appendages, lateral view; B — 3rd and 4th pleonal somites, lateral view; C — dactylus and propodus of left 3rd pereopod, lateral view; D — dactylus of left 3rd pereopod, lateral view. Scale bars: $5 \mathrm{~mm}$ for A, B; $1 \mathrm{~mm}$ for C, D.

Рис. 6. Eualus belcheri (Bell, 1855), самец (cl 15,2 мм), HUMZ-C 1425. А — карапакс и цефалические придатки, вид сбоку; В 3-й и 4-й плеональные сомиты, вид сбоку; C - дактиль и пропод левого переопода 3-й пары, вид сбоку; D - дактиль левого переопода 3-й пары, вид сбоку. Масштабные линейки: 5 мм для А, B; 1 мм для C, D.

First pereopod (Fig. 3D) not reaching midlength of antennal scale. Chela (Fig. 3E) about 1.5 times as long as carpus, 4.4 times longer than wide; dactylus about 0.7 times as long as palm, with 2 terminal claws; palm subcylindrical, fixed finger terminating in single claw. Merus with short row of spinules on ventral margin proximally. Ischium unarmed on ventral margin.

Second pereopod (Fig. 3F) overreaching antennal scale by length of chela. Carpus divided into 7 articles.

Third to fifth pereopods moderately slender, generally similar in structure and armature. Third pereopod (Fig. 3G) overreaching antennal scale by length of dactylus; dactylus (Fig. 3H, I) 0.40-0.46 (mean 0.43, $\mathrm{n}=13$ ) times as long as propodus, about 6.5 times longer than wide, armed with 7-9 slender accessory spinules on over entire length of flexor margin, unguis very slender, about twice length of distalmost accessory spinule; propodus with 2 rows of spinules on flexor margin; carpus about 0.4 length of propodus; merus subcylindrical, with 4-8 moderately spaced spines on lateral surface; ischium unarmed. Fourth pereopod (Fig. $3 \mathrm{~J})$ reaching or slightly overreaching antennal scale by half length of dactylus; dactylus about 0.4 times as long as propodus; merus with 3-6 spines on lateral surface. Fifth pereopod (Fig. 3K) not reaching distal margin of antennal scale; dactylus $0.3-0.4$ times as long as propodus; propodus with row of slender spinules on entire length of flexor margin and distal grooming apparatus; merus with 2-6 spines on lateral surface.

Uropodal protopod with posterolateral tooth gradually tapering; both rami overreaching posterior tip of telson (exopod slightly longer than endopod).

Males. Body more slender than in females. Rostrum (Fig. 4A) straight, 1.1 times as long as carapace, slightly overreaching distal margin of antennal scale. Third pleomere (Fig. 4B) posteriorly with prominent, acute, hook-like middorsal protuberance, making pleon gibbous. Corneal width about 0.2 of carapace length. Third pereopod with dactylus (Fig. 4C, D) $0.33-0.35$ (mean $0.34, \mathrm{n}=2$ ) times as long as propodus, about 5.5 times longer than wide, armed with 9 obliquely erect accessory spinules, ultimate accessory spinule contiguous to unguis, elongate, subequal in length to or slightly longer than unguis. 

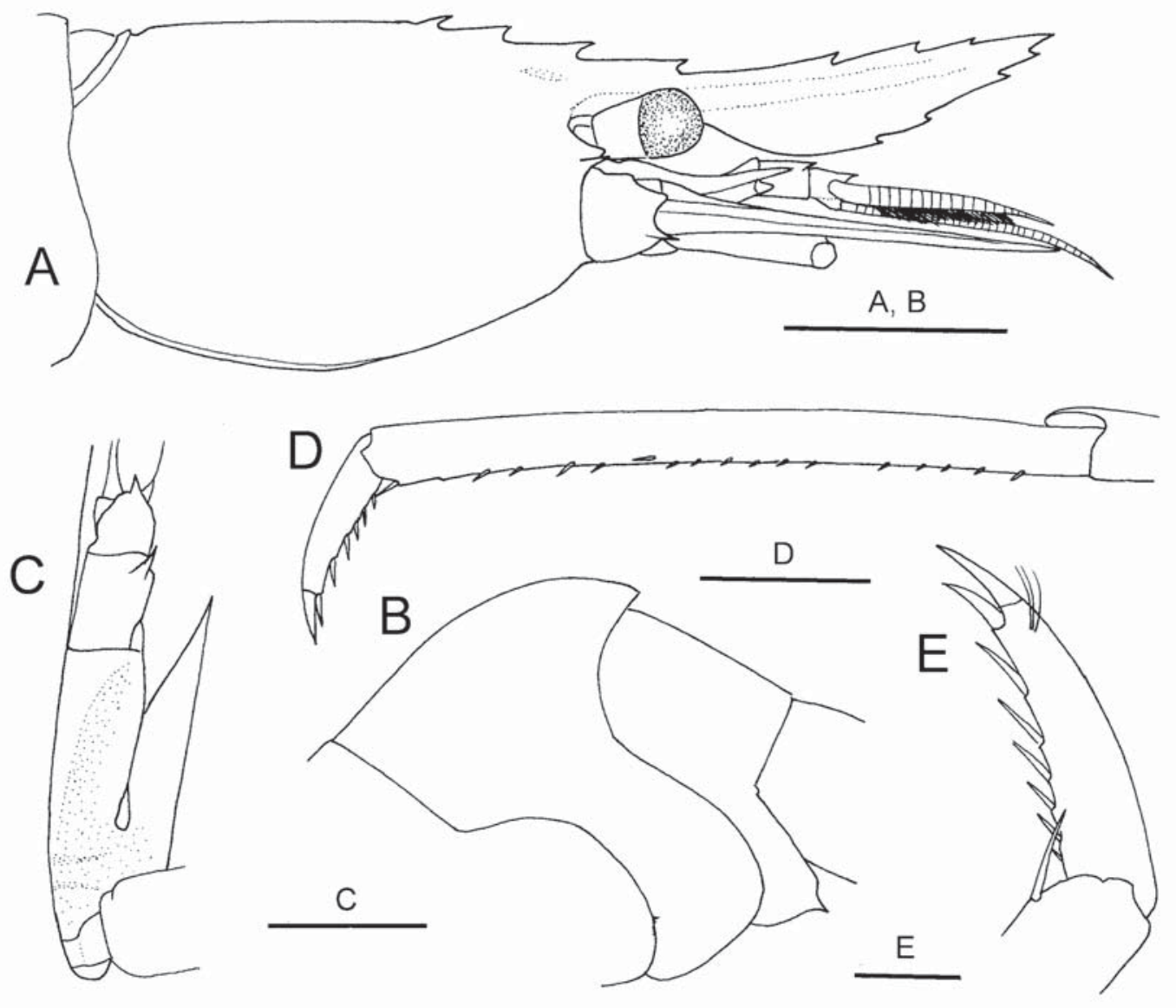

Fig. 7. Eualus gaimardii (H. Milne Edwards, 1837), ovigerous female (cl $10.3 \mathrm{~mm}$ ), HUMZ-C 1395. A — carapace and cephalic appendages, lateral view; B - 3rd and 4th pleonal somites, lateral view; C - right antennular peduncle, dorsal view; D - dactylus and propodus of left third pereopod, lateral view; E - dactylus of left 3rd pereopod, lateral view. Scale bars: $5 \mathrm{~mm}$ for A, B; $2 \mathrm{~mm}$ for C, D; $1 \mathrm{~mm}$ for $\mathrm{E}$.

Pис. 7. Eualus gaimardii (H. Milne Edwards, 1837), яйценосная самка (cl $10.3 \mathrm{~mm}$ ), HUMZ-C 1395. А — карапакс и цефалические придатки, вид сбоку; В - 3-й и 4-й плеональные сомиты, вид сбоку; С - правый стебелек антеннулы, вид сверху; $\mathrm{D}$ - дактиль и пропод левого переопода 3-й пары, вид сбоку; Е - дактиль левого переопода 3-й пары, вид сбоку. Масштабные линейки: 5 мм для А, B; 2 мм для C, D; 1 мм для Е.

Endopod of first pleopod (Fig. 4E) tapering distally into appendix interna slightly delimited at base. Endopod of second pleopod with appendix masculina (Fig. 4F) moderately slender (more than 6 times longer than basal width), subequal in length to appendix interna, bearing numerous long stiff setae on mesial surface to apex.

SIZE. Largest male cl $7.8 \mathrm{~mm}$; largest female cl $12.6 \mathrm{~mm}$; ovigerous females cl 10.1-12.6 mm.

VARIATION. Young females (cl 6.1-9.1 mm) differ from adult females (cl 9.6-12.6 mm) in the less conspicuous middorsal protuberance on the third pleonal tergite (cf. Fig. 2C and 2D). In addition, the dorsal margin of the rostrum is toothless in the distal 0.3 in those young females, although the dorsal margin of the rostrum is armed with teeth almost over the entire length in adults.

Notable sexual dimorphism is seen in the size and shape of the middorsal protuberance on the third pleomere and the relative length and the armature of the dactylus of the third pereopod (as well as fourth). The dactylus of the third pereopod is proportionally shorter in males than in females (proportion to the propodus $0.33-0.35$ in males versus about $0.40-0.46$ in females); accessory spinules on the flexor margin are stronger and more erect with the ultimate spinule being greatly elongate, slightly longer than the unguis in males.

DISTRIBUTION. Known with certainty only from the Bering Sea, at depths of 30-47 m.

ETYMOLOGY. Named for Nikolai A. Zarenkov, in recognition of his numerous contributions to the taxonomy of decapod crustaceans.

COMPARISON. Eualus zarenkovi sp. n. morphologically appears closest to E. gaimardii and E. belcheri, particularly in having a middorsal protuberance on the third pleomere (at least in males) and the possession of epipods on the first and second pereopods. The taxonomic status of E. gaimardii and its closely allied forms has not been settled satisfactorily. Traditionally, 


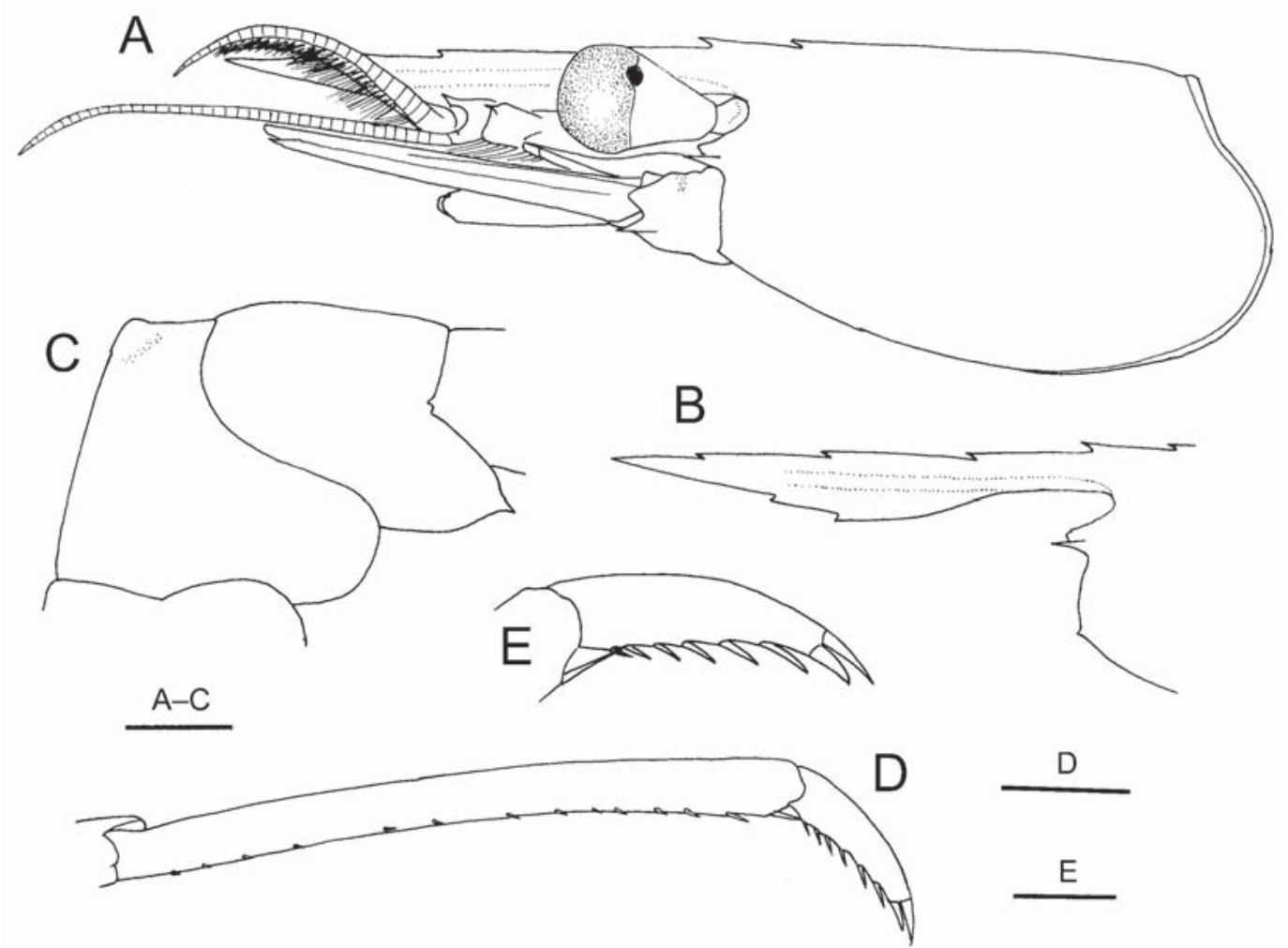

Fig. 8. Eualus gaimardii (H. Milne Edwards, 1837). Male (cl 7.7 mm), CBM-ZC (ex OUMNH-ZC 2003-31-0008). A - carapace and cephalic appendages, lateral view; B - rostrum, lateral view; C - 3rd and 4th pleonal somites, lateral view; D — dactylus and propodus of left 3rd pereopod, lateral view; E - dactylus of left 3rd pereopod, lateral view. Scale bars: $2 \mathrm{~mm}$ for A-C; $1 \mathrm{~mm}$ for D; $0.5 \mathrm{~mm}$ for E.

Pис. 8. Eualus gaimardii (H. Milne Edwards, 1837). Самец (cl 7.7 mm), CBM-ZC (еx OUMNH-ZC 2003-31-0008). А — карапакс и цефалические придатки, вид сбоку; В - 3- и 4-й плеональные сомиты, вид сбоку; С - правый стебелек антеннулы, вид сверху; D - дактиль и пропод левого переопода 3-й пары, вид сбоку; Е - дактиль левого переопода 3-й пары, вид сбоку. Scale bars: 2 мм для А-C; 1 мм для $\mathrm{D} ; 0,5$ мм для $\mathrm{E}$.

two or three subspecies or forms have been recognized in E. gaimardii, viz., the nominotypical form, gibba (Krøyer, 1841) and belcheri [e.g. Birula, 1910; Dons, 1915; Greve, 1963; Noël, 1978; Squires, 1990; Duriš, 1992, 1993; Smaldon, 1993; Komai, 1995; Chace, 1997; d'Udekem d'Acoz, Wirtz, 2002; Nygård et al., 2007]. On the other hand, Couture and Trudel [1968] and d'Udekem d'Acoz [1999] regarded E. belcheri as distinct from E. gaimardii at species level. d'Udekem d'Acoz [1999] further mentions that typical E. gaimardii are encountered at lower latitudes, with forma gib$b a$ being typical of high latitudes, but with numerous intermediate forms and thus considers forma gibba merely a synonym of $E$. gaimardii. Indeed, Hofsten [1916] had already argued that transitional morphs between the nominotypical taxa were apparent. In the latest treatment, De Grave and Fransen [2011] recognized only two subspecies, E. gaimardii gaimardii and E. gaimardii belcheri, and retained forma gibba under the synonymy of E. gaimardii gaimardii without comments.

Differentiating characters among E. zarenkovi sp.n., $E$. belcheri and E. gaimardii are summarized in Table 1 (see also below). The present comparison confirms that $E$. belcheri and E. gaimardii are distinct at species level, clearly distinguishable by morphological characters; as has been shown by previous studies [e.g. Squires, 1992; Komai, 1995]. Further, the geographical ranges of E. belcheri and E. gaimardii greatly overlap, indicating that subspecific rank for the two taxa is indeed not appropriate. The synonymy of $E$. gibba with $E$. gaimardii is supported, i.e., E. gibba corresponds to the male of E. gaimardii. Comparison among the three species should be made according to the sex, as they exhibit noticeable sexual dimorphism in some diagnostic characters, such as the rostral shape and armature, the development of the middorsal protuberance on the third pleomere and the proportional length and structure of the dactylus of the third pereopod.

The development of the middorsal protuberance on the third pleomere is different among the three species, providing easily observable feature for differentiation. In E. zarenkovi sp. n. and E. belcheri, both females and males have a middorsal protuberance on the third pleomere, but in females, the protuberance is less prominent and less acute in E. zarenkovi sp.n. than in $E$. belcheri (cf. Fig. 2C, D, versus Fig. 5B). In E. gaimardii, the third pleomere is dorsally rounded smoothly in females (Fig. 7B), while having a blunt middorsal protuberance in males (Fig. 8C). Eualus zarenkovi sp. n. can 
Table 1. Morphological comparison among Eualus zarenkovi sp.n., E. belcheri (Bell, 1855) and E. gaimardii (H. Milne Edwards, 1837).

Таблица 1. Морфологическое сравнение между Eualus zarenkovi sp.n., E. belcheri (Bell, 1855) and E. gaimardii (H. Milne Edwards, 1837).

\begin{tabular}{|c|c|c|c|}
\hline & E. zarenkovi sp.n. & E. belcheri & E. gaimardii \\
\hline \multicolumn{4}{|l|}{ Female } \\
\hline Rostrum length/cl & $1.10-1.48($ mean $1.25, \mathrm{n}=9)$ & $1.12-1.53($ mean $1.31, \mathrm{n}=17)$ & $\begin{array}{l}0.91-1.16(\text { mean } 1.04, \\
\mathrm{n}=8)\end{array}$ \\
\hline Number of dorsal teeth & $7-10$ & $6-7$ & $6-7$ \\
\hline Dorsal margin & unarmed on distal 0.2 or less & unarmed on distal $0.3-0.5$ & $\begin{array}{l}\text { unarmed on distal } 0.2 \text { or } \\
\text { less }\end{array}$ \\
\hline $\begin{array}{l}\text { Middorsal } \\
\text { protuberance on third } \\
\text { pleomere }\end{array}$ & $\begin{array}{l}\text { low, slightly hook-like (Fig. } \\
\text { 2C) or obsolescent in young } \\
\text { (Fig. 2D) }\end{array}$ & $\begin{array}{l}\text { prominent, acuminate, hook-like } \\
\text { (Fig. } 5 \mathrm{~B} \text { ) }\end{array}$ & absent (Fig. 7B) \\
\hline $\begin{array}{l}\text { Extension of } \\
\text { stylocerite }\end{array}$ & $\begin{array}{l}\text { not reaching midlength of } \\
\text { second peduncular segment } \\
\text { (Fig. 2B) }\end{array}$ & $\begin{array}{l}\text { reaching or overreaching distal } \\
\text { margin of second peduncular } \\
\text { segment (Fig. } 5 \mathrm{C} \text { ) }\end{array}$ & $\begin{array}{l}\text { not reaching midlength } \\
\text { of second peduncular } \\
\text { segment (Fig. 7C) }\end{array}$ \\
\hline $\begin{array}{l}\text { Dactylus } \\
\text { length/propodus length } \\
\text { (third pereopod) }\end{array}$ & $0.40-0.46($ mean $0.43, \mathrm{n}=13)$ & $0.20-0.25($ mean $0.22, \mathrm{n}=15)$ & $\begin{array}{l}0.28-0.34(\text { mean } 0.31 \\
\mathrm{n}=17)\end{array}$ \\
\hline Maximal size (cl) & $12.6 \mathrm{~mm}$ & $18.6 \mathrm{~mm}$ & $11.7 \mathrm{~mm}$ \\
\hline \multicolumn{4}{|l|}{ Male } \\
\hline Rostrum shape & straight (Fig. 4A) & gently upturned (Fig. 6A) & straight (Fig. 8A, B) \\
\hline Rostrum length/cl & $1.13(\mathrm{n}=1)$ & $1.21-1.45($ mean $1.32, \mathrm{n}=6)$ & $\begin{array}{l}1.15-1.23(\text { mean } 1.21 \\
\mathrm{n}=4)\end{array}$ \\
\hline $\begin{array}{l}\text { Middorsal } \\
\text { protuberance on third } \\
\text { pleomere }\end{array}$ & $\begin{array}{l}\text { acuminate, hook-like (Fig. } \\
\text { 4B) }\end{array}$ & acuminate, hook-like (Fig. 6B) & $\begin{array}{l}\text { blunt, not hook-like } \\
\text { (Fig. 8C) }\end{array}$ \\
\hline $\begin{array}{l}\text { Dactylus } \\
\text { length/propodus length } \\
\text { (third pereopod) }\end{array}$ & $\begin{array}{l}\text { about } 0.33-0.35 \text { (mean } 0.34 \text {, } \\
\mathrm{n}=2 \text { ) }\end{array}$ & $0.17-0.24($ mean $0.20, \mathrm{n}=5)$ & $\begin{array}{l}0.29-0.32(\text { mean } 0.30 \\
\mathrm{n}=5)\end{array}$ \\
\hline \multicolumn{4}{|l|}{ Both sexes } \\
\hline $\begin{array}{l}\text { Telson/pleomere } 6 \\
\text { length }\end{array}$ & $1.16-1.36($ mean $1.29, \mathrm{n}=14)$ & $1.43-1.53($ mean $1.48, \mathrm{n}=15)$ & $\begin{array}{l}1.15-1.34 \text { (mean } 1.23, \\
\mathrm{n}=14)\end{array}$ \\
\hline Dorsolateral spines & $5-9$ & $3-7$ & $3-6$ \\
\hline $\begin{array}{l}\text { Extension of third } \\
\text { maxilliped }\end{array}$ & $\begin{array}{l}\text { not reaching distal margin of } \\
\text { antennal scale (Fig. 1) }\end{array}$ & $\begin{array}{l}\text { reaching distal margin of } \\
\text { antennal scale }\end{array}$ & $\begin{array}{l}\text { not reaching distal } \\
\text { margin of antennal } \\
\text { scale }\end{array}$ \\
\hline
\end{tabular}

be distinguished from both E. belcheri and E. gaimardii by having more numerous dorsal rostral teeth in females (7-10 versus $6-7)$, and the proportionally longer dactylus of the third pereopod (for details, see Table 1). Among the three species, E. belcheri has the shortest dactylus of the third pereopod. The telson can have more numerous dorsolateral spines in E. zarenkovi sp. n. than in the other two species, although the counts partially overlap (Table 1). Furthermore, E. zarenkovi sp.n. and $E$. gaimardii differ from E. belcheri in the armature on the dorsal margin of the rostrum in females (unarmed in distal 0.2 or less versus distal $0.3-0.5$ ), the proportionally shorter telson, shorter antennular stylocerite (not reaching the distal margin of the second segment of the anten- 
nular peduncle versus reaching or slightly overreaching it; cf. Fig. 2A, B and Fig. 5C), and the shorter third maxilliped (falling short of the distal margin of the antennal scale versus reaching it). With regard to overall size, E. belcheri attains a larger size than the other two species do (Table 1). In the male, the rostrum is nearly straight in E. zarenkovi sp.n. (Fig. 4A) and E. gaimardii (Fig. 8B), whereas gently upturned, being similarly to females, in E. belcheri (Fig. 6A).

Rathbun [1904] reported Spirontocaris gaimardii belcheri on the basis of material from the Bering Sea, Chukchi Sea and the waters of the Canadian Arctic Archipelago. Her description agrees better with E. $z a-$ renkovi sp.n. than with $E$. belcheri. The male and female specimens shown in a photograph (Plate 3, fig. 3, 3a), collected at "Albatross" station 3519, off St. Matthew Island in the eastern Bering Sea, agree well with E. zarenkovi sp. n., particularly in the shape and development of the middorsal protuberance on the third pleomere and the proportionally long and slender dactylus of the third pereopod. Consequently, Rathbun's [1904] record of Spirontocaris gaimardii belcheri is partially referred to E. zarenkovi sp.n.

\section{Identity of Eualus ratmanovi Makarov, 1941}

Makarov [1941] described a new species, Eualus ratmanovi, on the basis of material from the Bering Sea. He compared his new taxon with E. belcheri (as $E$. gaimardii belcheri). Since the original description, no subsequent records of E. ratmanovi have been made, although some workers have mentioned the species [e.g. Vinogradov, 1950; Birshtein, Vinogradov, 1953; Chace, 1997; De Grave, Fransen, 2011]. Because of the insufficient original description, the specific identity of Makarov's taxon remains rather obscure [see Nöel, 1978]. In the original description of E. ratmanovi, Makarov [1941] mentioned specimens from five stations of the Bering Expedition, but did not designate a holotype nor specify how many specimens were examined. The specimens mentioned in the original description are thus considered to be syntypes.

According to Makarov [1941], E. ratmanovi is distinguished from E. belcheri by a different shape and armature of the rostrum, the different shape of the distal lamella of the antennal scale, relatively larger eye, proportionally shorter dactyli of the posterior three pairs of pereopods with fewer accessory spinules on flexor margins, the presence of a prominent hook-shaped middorsal protuberance on the third pleomere not only in males but in females too, the relatively shorter sixth pleomere and the longer telson. As is apparent from the above comparison, however, E. ratmanovi agrees rather well with E. belcheri, and E. belcheri sensu Makarov [1941] agrees with E. zarenkovi sp.n. in all but the two characters cited by Makarov [1941]. In our material, no significant differences were observed in the shape of the distal lamella of the antennal scale and the size of the eye between the two species; counts of the acces- sory spinules on dactyli of ambulatory legs overlap between $E$. belcheri and E. zarenkovi sp. n. We herein postulate that Makarov [1941] studied a mixed collection of both species, with the main part of the description of E. ratmanovi (and Fig. 9) being based on specimens of true $E$. belcheri (as herein interpreted) and material assigned by him to E. belcheri being in reality E. zarenkovi sp.n. In the interest of nomenclatural stability, we herein designate the specimen illustrated (see Article 74.4, ICZN 1999) by Makarov [1941] in Fig. 9, as the lectotype of Eualus ratmanovi Makarov, 1941. This specimen is catalogued in the ZIN RAN collection under number $6 / 57265$ and has the following metadata: Bering Sea, Trawler "Krasnoarmeets", Stn 16, $63^{\circ} 16^{\prime} \mathrm{N} 179^{\circ} 16^{\prime} \mathrm{W}, 78 \mathrm{~m}$, stone, pebble, T $1.33 \mathrm{C}, \mathrm{S}$ 33.28 psu, beam trawl, coll. N. Kondakov, 30.07.1933. The specimen is male, has a carapace length of $9.5 \mathrm{~mm}$ and is generally in good condition. However, only the left fifth pereopod, as well as both first and second pereopods are present, with the remaining ambulatory pereiopods missing. This action effectively makes $E$. ratmanovi Makarov, 1941 a junior synonym of $E$. belcheri (Bell, 1855).

ACKNOWLEDGEMENTS. We deeply thank Dr. Mamoru Yabe (HUMZ) for making the valuable specimens, collected by himself on board TRV "Oshoro-maru", available for study, and for loaning further comparative material used in this study. Thanks are extended to Dr. Hisashi Imamura (HUMZ) for providing us with literature. Drs Vassily A. Spiridonov and V.V. Petryashov (ZIN RAN) provided invaluable assistance in tracking down the type material of Eualus ratmanovi in St Petersburg.

\section{References}

Birula A. 1910. Beiträge zur Kenntnis der Decapoden-Krebse der eurasiatischen Arctis // Mémoires de l'Académie Impériale des Sciences de St.-Pétersbourg. Sér.8. Vol.29. P.1-42, pl. 1.

Birshtein Y.A., Vinogradov L.G. 1953. [New data on the decapod crustacean fauna in the Bering Sea] // Zoologischeskii Zhurnal. Vol.79. P.215-228 [in Russian]

Brashnikov V. 1907. Matériaux pour servir á la connaissance de la faune des mers russes de l'Est rassemblés par de schooner "Storoz" en 1899-1902 // Mémoires de l'Académie Impériale des Sciences de St-Pétersbourg. Classe des Sciences Physiques et Mathématiques. Sér.8. Vol.20. P.i-ii, 1-185.

Carvacho A., Olson R. 1984. Nuevos registros para la fauna carcinologica del noreste de Mexico y description de una nueva especie: Eualus subtilis n. sp. (Crustacea: Decapoda: Natantia) // The Southwestern Naturalist. Vol.29. P.59-71.

Chace F.A., Jr. 1997. The caridean shrimps (Crustacea: Decapoda) of the Albatross Philippine Expedition, 1907-1910, Part 7: Families Atyidae, Eugonatonotidae, Rhynchocinetidae, Bathypalaemonellidae, Processidae and Hippolytidae // Smithsonian Contributions to Zoology. Vol.587. P.1-106.

Couture R., Trudel P. 1968. Les crevettes des eaux côtières du Québec. Taxonomie et distribution // Naturaliste Canadien. Vol.95. P.857-885.

De Grave S., Fransen C.H.J.M. 2011. Carideorum catalogus: the recent species of dendrobranchiate, stenopodidean, procarididean and caridean shrimps (Crustacea: Decapoda) // Zoologische Mededelingen. Vol.85. P.195-588.

De Grave S., Li C.P., Tsang L.M., Chu K.H., Chan T.-Y. 2014. Unweaving hippolytoid systematics (Crustacea, Decapoda, Hip- 
polytidae): resurrection of several families // Zoologica Scripta. Vol.43. P.496-507.

Dons C. 1915. Nord-Norges Decapoder // Tromsø Museums Aarshefter. Vol.37. P.15-153, pls 1, 2.

Duriš Z. 1992. On a small collection of Crustacea Decapoda from the Bellsund region, Spitzbergen // Wyprawy Geograficzne na Spitzbergen UMCS, Lublin 1992. P.121-149.

Duriš Z. 1993. On a collection of Crustacea Decapoda from the southeastern Svalbard // XX Polar Symposium, Lublin 1993. P.141-157.

Greve L. 1963. The genera Spirontocaris, Lebbeus, Eualus and Thoralus in Norwegian waters (Crust. Dec.) // Sarsia. Vol.11. P.29-42.

Hayashi K.I. 1993. Prawns, shrimps and lobsters from Japan (72) Family Hippolytidae - Genus Eualus // Aquabiology. Kan.15. P.241-244, 311-314, 390-393 [in Japanese].

Hofsten N. von. 1916. Die Decapoden Crustaceen des Eisfjords. Zoologische Ergebnisse der schwedischen Expedition nach Spitsbergen, 1908 // Kungliga Svenska Vetenskapsakademien Handligar. Bd.54. H.7. P.1-198, Pls 1-2.

Holthuis L.B. 1950. Fauna van Nederland 15. Decapoda A. Natantia, Macrura Reptantia, Anomura en Stomatopoda. Leiden: A.W. Sijthoff's Uitgeversmaatschappi N.V. 166 p.

International Commission on Zoological Nomenclature (ICZN) 1999. International Code of Zoological Nomenclature 4th Edition. London: The International Trust for Zoological Nomenclature. 306 p.

Kobjakova Z.I. 1937. [Systematisch Übersicht der Dekapoden aus dem Okhotskischen und dem Japanischem Meere] // Uchenye Zapiski Leningradskogo Universiteta. Vol.15. P.93-154 [in Russian, with German summary].

Kobjakova Z.I. 1955. [New species of Crustacea Decapoda from southern part of Kurile-Sakhalin region] // Trudy Zoologicheskogo Instituta Akademii Nauk SSSR. Vol.18. P.235-242 [in Russian].

Komai T. 1995. Sergestidae, Oplophoridae, Pasiphaeidae, Hippolytidae, Pandalidae, Crangonidae, and Polychelidae // Okamura O. et al. (eds.). Fishes Collected by the R/V Shinkai Maru around Greenland. Tokyo: Japan Marine Fishery Resources Research Center. P.237-266.

Komai T., Fujiwara Y. 2012. Description of a new species of the hippolytid shrimp genus Eualus Thallwitz, 1892 from Japan, and clarification of the status of E. kikuchii Miyake \& Hayashi, 1967 (Crustacea: Decapoda: Caridea) // Zootaxa. Vol.3546. P.68-80.

Komai T., Hayashi K. 2002. A new species of the hippolytid shrimp genus Eualus Thallwitz, 1891 (Crustacea: Decapoda:
Caridea) from Toyama Bay, the Sea of Japan // Proceedings of the Biological Society of Washington. Vol.115. P.382-390.

Makarov V.V. 1941. [The decapod Crustacea of the Bering and Chukchees seas] // Issledovaniya Dalnevostochnykh Morei SSSR. Vol.1. P.111-163 [in Russian, with English summary]. Miyake S., Hayashi K. 1967. Studies on the hippolytid shrimps from Japan, I. Revision of the Japanese species of the genus Eualus, with description of two new species // Journal of the Faculty of Agriculture, Kyushu University. Vol. 14. P. 247-265.

Noël P. 1978. Eualus drachi nov. sp. (Crustacea, Caridea, Hippolytidae) des côtes française de la Mediterranée // Archives de Zoologie Expérimentale et Générale, Paris. Vol.119. P.21-38.

Nye V. 2013. New species of hippolytid shrimps (Crustacea: Decapoda: Caridea: Hippolytidae) from a southwest Indian Ocean seamount // Zootaxa. Vol.3637. P.101-112.

Nygård H., Berge J., Gulliksen B., Camus L. 2007. The occurrence of Eualus gaimardii gibba Krøyer 1841 (Crustacea, Decapoda) in the sympagic habitat: an example of bentho-sympagic coupling // Polar Biology. Vol.30. P.1351-1354.

Rathbun M.J. 1904. Decapod crustaceans of the northwest coast of North America // Harriman Alaska Expedition. Vol.10. P.1190, pls $1-10$.

Smaldon G. 1993. Synopses of the British Fauna (New Series) No.15. Coastal Shrimps and Prawns. Second Edition, Revised and Enlarged by L.B. Holthuis and C.H.J.M. Fransen. London: The Linnean Society of London and The Estuary and Coastal Sciences Association. 142 p.

Squires H.J. 1990. Decapod Crustacea of the Atlantic coast of Canada // Canadian Bulletin of Fisheries and Aquatic Sciences. Vol.221. P.i-viii, 1-532.

Udekem d'Acoz C. d'. 1999. Inventaire et distribution des crustacés décapodes de l'Atlantique nord-oriental, de la Méditerranée et des eaux continentales adjacentes au nord de $25^{\circ} \mathrm{N} / /$ Patrimoines Naturels. Vol.40. P.i-X, 1-383.

Udekem d'Acoz C. d', Wirtz P. 2002. Observations on some interesting coastal Crustacea Decapoda from the Azores, with a key to the genus Eualus Thallwitz, 1892 in the northeastern Atlantic and the Mediterranean // Arquipélago, Bulletin of the University of the Azores, Life and Marine Sciences. Vol.19A. P.67-84.

Vinogradov L.G. 1950. [Classification of shrimps, prawns and crabs from Far East] // Izvestiya TINRO. Vol.33. P.179-358 [in Russian].

Wicksten M.K. 1990. Key to the hippolytid shrimp of the Eastern Pacific Ocean // Fishery Bulletin, U.S. Vol.88. P.587-598.

Responsible editor V.A. Spiridonov 